\title{
The effect of Zostera noltii, Spartina maritima and Scirpus maritimus on sediment pore-water profiles in a temperate intertidal estuary
}

\author{
A.I. Lilleb $\wp^{1, *}$, M.R. Flindt ${ }^{2}$, M.A. Pardal ${ }^{1} \&$ J.C. Marques ${ }^{1}$ \\ ${ }^{1}$ IMAR - Institute of Marine Research, Department of Zoology, University of Coimbra, 3004-517, Coimbra, Portugal \\ ${ }^{2}$ Biological Institute, SDU - University of Odense, Campusvej 55, 5230, Odense M, Denmark \\ (*Author for correspondence: Tel.: +351-239-837797; Fax: +351-239-823603; E-mail: lillebo@ci.uc.pt)
}

Key words: salt marsh, nutrient profiles, estuary, nitrogen, phosphorus

\begin{abstract}
The objective of the present work was to study the effect of plants common in temperate latitudes (Zostera noltii, Spartina maritima and Scirpus maritimus) on sediment nutrient profiles, and to compare it to sandand mud-flats without vegetation. The study focused on the organic matter contents, the concentration of dissolved inorganic nutrients $\left(\mathrm{PO}_{4}-\mathrm{P}, \mathrm{NH}_{3}-\mathrm{N}, \mathrm{NO}_{3}-\mathrm{N}\right)$, an on the estimation of the total amount of these nutrients during day and night conditions and their potential net-fluxes. It was also hypothesised that in an estuarine system, different plants may have specific effects, and consequently different contributions to the system nutrient dynamics as a whole. Sediment profiles of loss on ignition (LOI) showed an increase of the organic matter contents from sand-flat, to Zostera, Spartina, mud-flat and Scirpus. Statistically, there were significant differences between sediment profiles of phosphate, ammonia and nitrate (Mann-Whitney test, $p<0.05$ ), during day and night periods. These results suggest that there is an intense mobility of nutrients in the sediment, showing a day-night variation of nutrient concentrations in the pore-water. In the plants' rhizosphere, the day-night variation of nutrients seemed dependent on plant biomass and penetration of the roots. Additionally, coupling between plant and sediment seems to be a species-specific process. In spring, Scirpus salt marsh reaches the maximum density and biomass, and despite the higher organic matter contents in the plant covered sediment, Scirpus acts as a sink of nutrients. In contrast, the top $10 \mathrm{~cm}$ of the sediment in the Spartina salt marsh and in the Zostera beds may contribute to the efflux of nutrients during the night period, especially phosphate.
\end{abstract}

\section{Introduction}

Salt marshes and sea-grass beads have been characterised as efficient sinks for nutrients, and buffering the effects of nutrient inputs, (e.g., Anderson et al., 1997; Andersen \& Ring, 1999; Flindt et al., 1999). The root-sediment interaction is complex and covers a wide range of biogeochemical processes, (e.g., Caçador et al., 1996; Wigand et al., 1997). Vegetation may also act as sediment traps playing an important role in the settling of suspended matter (Kamp-Nielsen \& Flindt, 1993; Caçador et al., 1996, 2000; Andersen \& Ring,
1999; Flindt et al., 1999). Several papers have reported chemical changes in the rhizosphere of several plants, including the redox potential (Eh), organic matter contents, metal availability and oxygen and nutrient profiles, (e.g. Kamp-Nielsen \& Flindt, 1993; Caçador et al., 1996, 2000; Anderson et al., 1997; Cartaxana \& Lloyd, 1999; Flindt et al., 1999; Azzoni et al., 2001). Nonetheless, few papers have addressed comparative studies of different plants in natural estuarine environments (Wigand et al., 1997; Sánchez et al., 1998). It was hypothesised that different plants may have different specific effects, and consequently 
different contributions to the system nutrient dynamics as a whole.

The Mondego estuary is located on the Atlantic coast of Portugal $\left(40^{\circ} 08^{\prime} \mathrm{N}, 8^{\circ} 50^{\prime} \mathrm{W}\right)$. It is about $7 \mathrm{~km}$ long and $2-3 \mathrm{~km}$ across at its widest part. Wetland habitats occupy about $18 \%$ of the south arm of the Mondego estuary, where the Scirpus maritimus L. population occupies the inner mudflat areas, Spartina maritima (Curtis) Fernald occurs in the higher downstream mud-flat and sand-flat areas, and the Zostera noltii Hornem beds occupy the downstream mud-flats (Fig. 1). In the 1980s, Z. noltii beds occupied a broad expanse along the southern arm reaching the inner most parts of the estuary. Nowadays, this grass-like flowering plant has become restricted to a small patch located downstream, having been replaced elsewhere by green macroalgae (Marques et al., 1997, 2003; Cardoso et al., 2002). These three species also differ in their annual dynamics. New leaves of $Z$. noltii appear in late winter (late February/March) and the eelgrass meadows develop over the intertidal mud-flats in spring/ summer. Leaf cover begins to decline during autumn/winter. S. maritima is a rhizomatous grass forming extensive monotypic stands (Sánchez et al., 1997), with a continuous but very slow growth (Adams \& Bate, 1995). S. maritimus is a stoutly rhizomatous perennial sedge (Karagatzides \& Hutchinson, 1991), and usually forms similar dense monospecific stands in shallow brackish marshes (Lieffers \& Shay, 1982). In the Mondego estuary this species has a particularly aboveground life cycle with a growing season from January to April/May (Lillebø et al., 2003).

The objective was to study the sediment profiles at $Z$. noltii meadows and on the $S$. maritima and $S$. maritimus salt marshes in comparison with sand and mud-flats without vegetation, concerning: the organic matter contents; the dissolved inorganic nutrients $\left(\mathrm{PO}_{4}-\mathrm{P}, \mathrm{NH}_{3}-\mathrm{N}, \mathrm{NO}_{3}-\mathrm{N}\right)$ followed by an estimation of the total amount of these nutrients during day and night conditions; and finally compare the potential net-fluxes. This study took place in May, because spring corresponds to the season where $S$. maritimus and $Z$. noltii reaches maximum

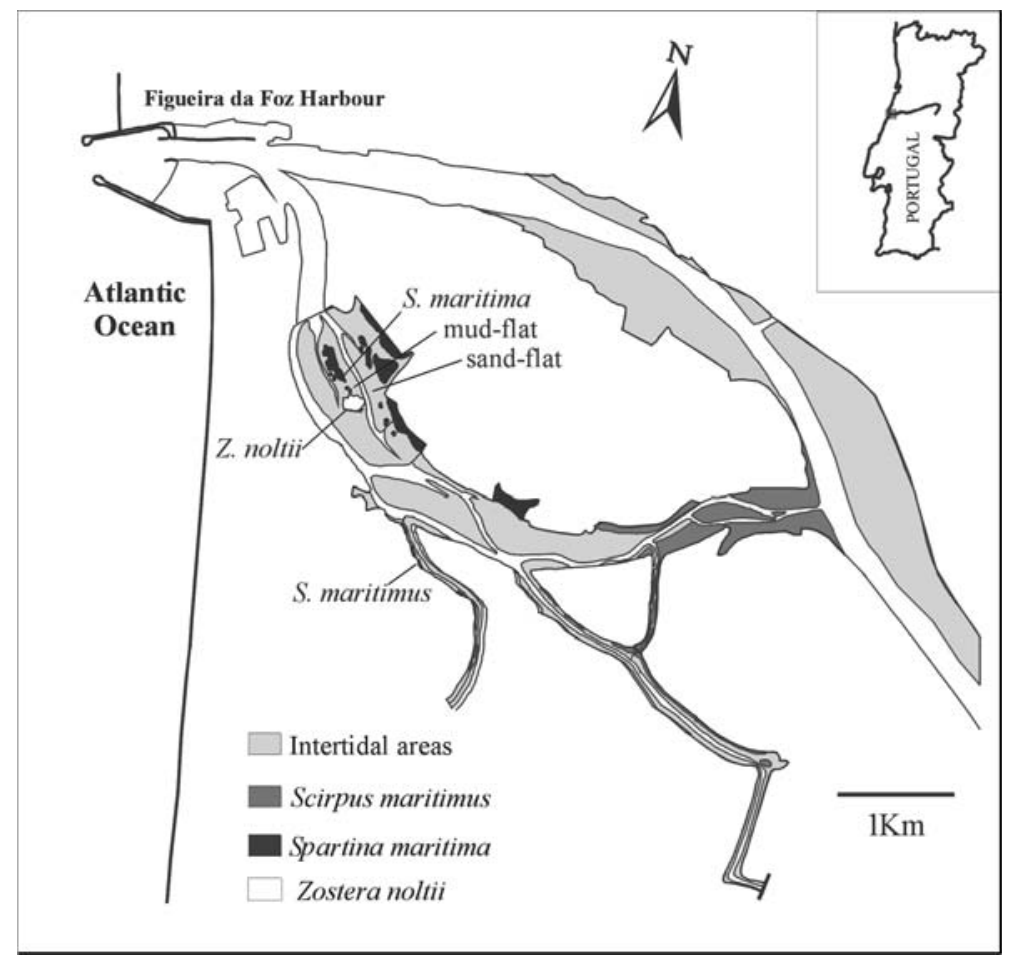

Figure 1. The location of the Mondego estuary and location of the study sites: Spartina and Scirpus salt marshes, Zostera meadows and mud- and sand-flats without vegetation. 
aboveground biomass. The mean above and belowground biomass (Mean \pm STD) in spring is, respectively, $51 \pm 29 \mathrm{~g}$ Dwt $\mathrm{m}^{2}$ and $25 \pm 8 \mathrm{~g}$ Dwt $\mathrm{m}^{2}$ for Zostera, $1866 \pm 679 \mathrm{~g}$ Dwt $\mathrm{m}^{2}$ and $2183 \pm 1119 \mathrm{~g}$ Dwt $\mathrm{m}^{2}$ for Spartina, and $435 \pm 273 \mathrm{~g}$ Dwt $\mathrm{m}^{2}$ and $3374 \pm 890 \mathrm{~g}$ Dwt $\mathrm{m}^{2}$ for Scirpus, in IMAR-Data base and Lillebø et al. (2003).

\section{Material and methods}

Five different study areas were established in the southern arm of the Mondego estuary on the 18th of May 2000: a bare sediment mud-flat; a sand-flat area; the Zostera beds; the Spartina salt marsh; and the Scirpus salt marsh. In order to characterise each area, triplicate sediment cores $(10 \mathrm{~cm}$ depth) were analysed $(1 \mathrm{~cm}$ slices $)$ for percentage of water contents (Wwt-Dwt, $105{ }^{\circ} \mathrm{C}$ for $24 \mathrm{~h}$ ), and loss on ignition (LOI) (Dwt-AFDW, $550^{\circ} \mathrm{C}$ for $6 \mathrm{~h}$ ). Sediment nutrient profiles were studied by placing vertically dialysis chambers in the muddy and sandy bare sediments and in the plants' rhizospheres; for a more detailed description of the technique see Kamp-Nielsen \& Flindt (1993). In our case, the water samples were collected with a syringe $(2.5 \mathrm{ml}$, corresponding to each chamber volume), and simultaneously the chamber was filled up with distilled water. To evaluate the effect of plants, samples were taken after $12 \mathrm{~h}$ exposure under dark conditions (night period) and $12 \mathrm{~h}$ under light conditions (day).

All water samples were analysed for dissolved inorganic phosphate, ammonia and nitrate in a rapid flow autoanalyser (RFA 300 Alpkem) according to Alpkem methodologies (1990). A nonparametric Mann-Whitney test was applied to determine the significance of differences $(95 \%$ confidence level) between the sediment nutrient profiles (Zar, 1996).

Estimates of the amount of nutrients in the sediment at each depth were performed considering the LOI, the nutrient concentration in the interstitial water, the sediment sample specific mass and the water volume fraction. The total amount was obtained by integration of the amounts through depth.

Possible night efflux rates were calculated taking into account the difference between the night and day total amount plus the estuarine area occupied by each species population $\left(\right.$ Zostera $=8850 \mathrm{~m}^{2}, \quad$ Spartina $=104720 \mathrm{~m}^{2}$ and Scirpus $=105863 \mathrm{~m}^{2}$ ).

\section{Results}

The profiles of percentage of LOI in the sediment indicate an increase of organic matter from sandflat, to Zostera, Spartina and to mud-flat (Fig. 2). Scirpus marshes, located in the most inner estuarine areas, with lower hydrodynamics and higher sedimentation of fine sediments, showed a higher percentage of LOI.

Phosphate and ammonia concentrations in sediment pore-water increased with depth, especially in Zostera (Fig. 3a and b) and in the mudflat (Fig. 4a and b) profiles, and during the night. On the other hand, nitrate concentrations were

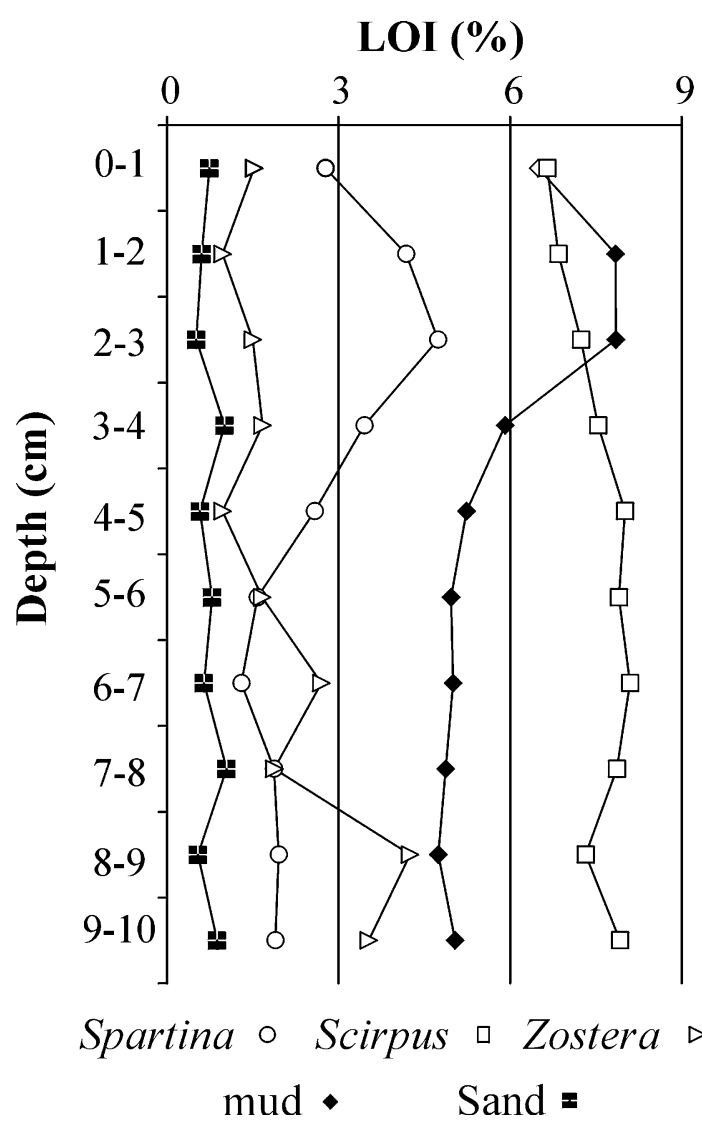

Figure 2. The profile of sediment LOI in Spartina, Scirpus and Zostera rhizosphere, and in mud- and sand-flats without vegetation. 


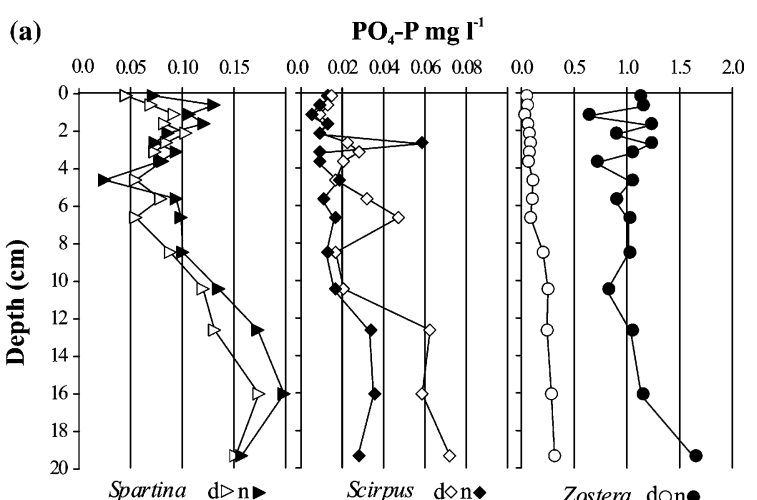

(b)

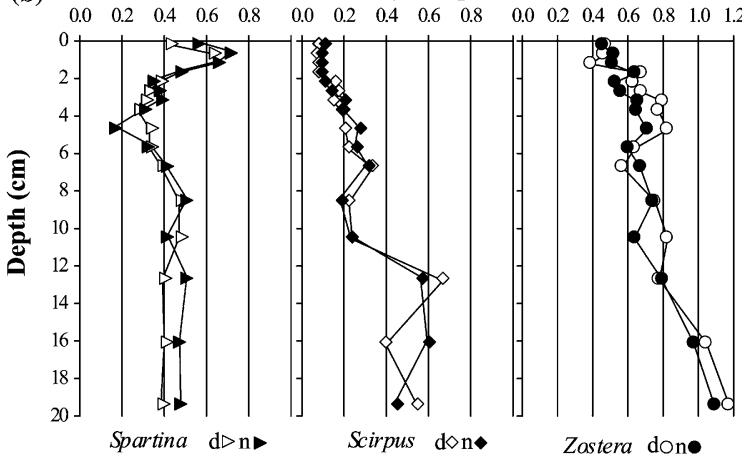

(c)

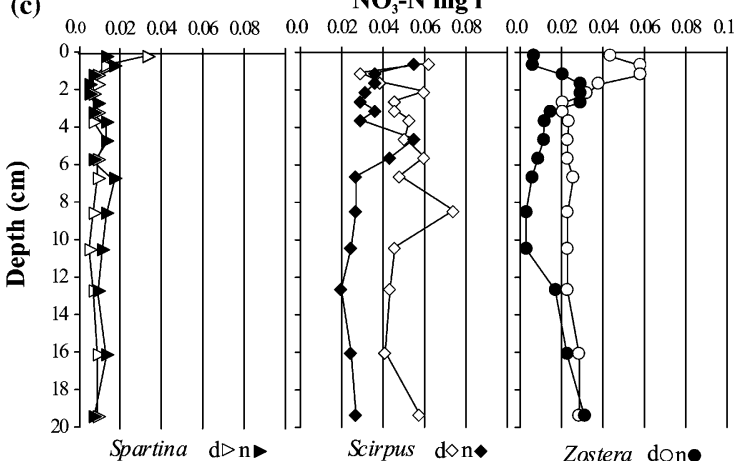

Figure 3. Nutrient concentrations in sediment pore-water profiles in Spartina, Scirpus and Zostera rhizosphere, during day and night: (a) Phosphate; (b) Ammonia; (c) Nitrate.

higher during the day and tended to decrease with depth, except for Scirpus rhizosphere were it was quite constant (Fig. 3c), and in the sand-flat were it only slightly increased (Fig. 4c).

The non-parametric Mann-Whitney tests showed that day-night profiles were significantly different in the mud and sand-flats without
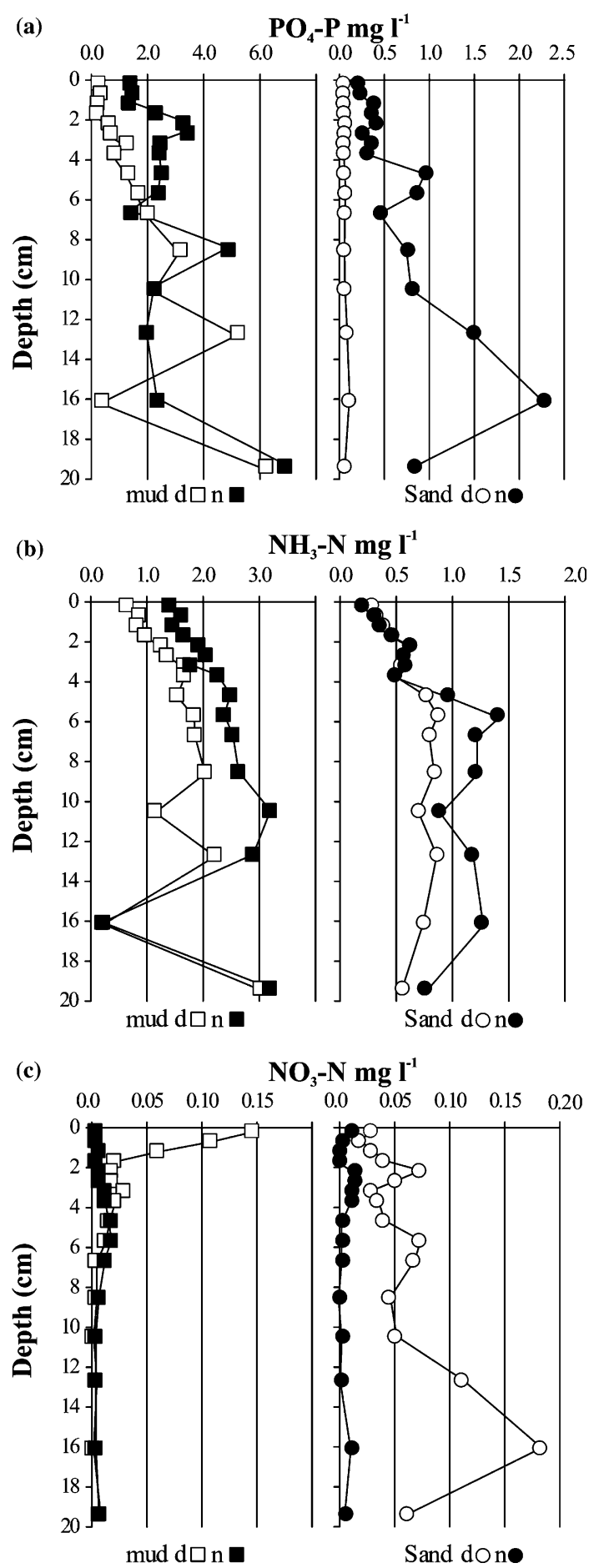

Figure 4. Nutrient concentrations in sediment pore-water profiles mud- and sand-flats without vegetation, during day and night: (a) Phosphate; (b) Ammonia; (c) Nitrate. 
vegetation (Table 1A). In the vegetated flats, day-night profiles were statistically different for $\mathrm{PO}_{4}-\mathrm{P}$ and $\mathrm{NO}_{3}-\mathrm{N}$ in $Z$. noltii rhizosphere and for $\mathrm{NO}_{3}-\mathrm{N}$ in $S$. maritimus rhizosphere. In the Spartina rhizosphere there were no statistically significant differences between day and night

Table 1. Results from the non-parametric Mann-Whitney expressing the significance of differences ( $95 \%$ confidence level) in sediment $\mathrm{PO}_{4}-\mathrm{P}, \mathrm{NH}_{3}-\mathrm{N}$ and $\mathrm{NO}_{3}-\mathrm{N}$ profiles

\begin{tabular}{|c|c|c|c|c|c|c|}
\hline & & Mud-flat & Sand-flat & Spartina maritima & Scirpus maritimus & Zostera nolti \\
\hline \multicolumn{7}{|c|}{ A: Between day and night concentrations } \\
\hline \multirow[t]{5}{*}{$\mathrm{PO}_{4}-\mathrm{P}$} & Mud-flat & 0.0079 & - & - & - & - \\
\hline & Sand-flat & - & 0.0000 & - & - & - \\
\hline & Spartina maritima & - & - & n.s. & - & - \\
\hline & Scirpus maritimus & - & - & - & n.s. & - \\
\hline & Zostera noltii & - & - & - & - & 0.0000 \\
\hline \multirow[t]{5}{*}{$\mathrm{NH}_{3}-\mathrm{N}$} & Mud-flat & 0.0136 & - & - & - & - \\
\hline & Sand-flat & - & n.s. & - & - & - \\
\hline & Spartina maritima & - & - & n.s. & - & - \\
\hline & Scirpus maritimus & - & - & - & n.s. & - \\
\hline & Zostera noltii & - & - & - & - & n.s. \\
\hline \multirow[t]{5}{*}{$\mathrm{NO}_{3}-\mathrm{N}$} & Mud-flat & n.s & - & - & - & - \\
\hline & Sand-flat & - & 0.0000 & - & - & - \\
\hline & Spartina maritima & - & - & n.s. & - & - \\
\hline & Scirpus maritimus & - & - & - & 0.0017 & - \\
\hline & Zostera noltii & - & - & - & - & 0.0033 \\
\hline \multicolumn{7}{|c|}{ B: Between concentrations during day } \\
\hline \multirow[t]{4}{*}{$\mathrm{PO}_{4}-\mathrm{P}$} & Sand-flat & 0.0000 & - & - & - & \\
\hline & Spartina maritima & 0.0000 & 0.0003 & - & - & \\
\hline & Scirpus maritimus & 0.0000 & 0.0034 & 0.0000 & - & \\
\hline & Zostera noltii & 0.0000 & 0.0001 & n.s. & 0.0000 & \\
\hline \multirow[t]{4}{*}{$\mathrm{NH}_{3}-\mathrm{N}$} & Sand-flat & 0.0002 & - & - & - & \\
\hline & Spartina maritima & 0.0000 & 0.0109 & - & - & \\
\hline & Scirpus maritimus & 0.0000 & 0.0001 & 0.0007 & - & \\
\hline & Zostera noltii & 0.0006 & n.s. & 0.0002 & 0.0000 & \\
\hline \multirow[t]{4}{*}{$\mathrm{NO}_{3}-\mathrm{N}$} & Sand-flat & 0.0022 & - & - & - & \\
\hline & Spartina maritima & n.s. & 0.0000 & - & - & \\
\hline & Scirpus maritimus & 0.0014 & n.s. & 0.0000 & - & \\
\hline & Zostera noltii & 0.0129 & 0.0033 & 0.0000 & 0.0002 & \\
\hline \multicolumn{7}{|c|}{ C: Between concentrations during night } \\
\hline \multirow[t]{4}{*}{$\mathrm{PO}_{4}-\mathrm{P}$} & Sand-flat & 0.0000 & - & - & - & \\
\hline & Spartina maritima & 0.0000 & 0.0000 & - & - & \\
\hline & Scirpus maritimus & 0.0000 & 0.0000 & 0.0000 & - & \\
\hline & Zostera noltii & 0.0000 & 0.0021 & 0.0000 & 0.0000 & \\
\hline \multirow[t]{4}{*}{$\mathrm{NH}_{3}-\mathrm{N}$} & Sand-flat & 0.0000 & - & - & - & \\
\hline & Spartina maritima & 0.0000 & 0.0167 & - & - & \\
\hline & Scirpus maritimus & 0.0000 & 0.0001 & 0.0016 & - & \\
\hline & Zostera noltii & 0.0000 & n.s. & 0.0004 & 0.0000 & \\
\hline \multirow[t]{4}{*}{$\mathrm{NO}_{3}-\mathrm{N}$} & Sand-flat & n.s. & - & - & - & \\
\hline & Spartina maritima & 0.0205 & 0.0065 & - & - & \\
\hline & Scirpus maritimus & 0.0000 & 0.0000 & 0.0000 & - & \\
\hline & Zostera noltii & 0.0134 & 0.0038 & n.s. & 0.0003 & \\
\hline
\end{tabular}


profiles considering the three nutrients analysed (Table 1A).

The nutrient profiles in the mud- and sand-flat without vegetation were statistically different from each other and from all other studied areas during day (Table 1B) and night situations (Table 1C). There were statistically significant differences concerning the concentrations of the three nutrients analysed between Spartina and Scirpus rhizosphere profiles and between Spartina and Zostera rhizosphere profiles, under day and night situations. Scirpus and Zostera rhizosphere were also statistically different for $\mathrm{PO}_{4}-\mathrm{P}, \mathrm{NH}_{3}-\mathrm{N}$ and $\mathrm{NO}_{3}-\mathrm{N}$ during the day (Table 1B) and night (Table 1C).

The total amount of phosphate in the first $10 \mathrm{~cm}$ of sediment was lower in the sand-flat, increasing in Scirpus, Spartina and in Zostera rhizosphere, and was much higher in the mud-flat without vegetation (Fig. 5a). The total amount of ammonia was lower in Scirpus rhizosphere, increasing in the sand-flat, Zostera rhizosphere, mud-flat and was highest in Spartina rhizosphere (Fig. 5b). Nitrate total amount was higher in Scirpus rhizosphere, decreasing in Spartina and Zostera rhizosphere, in sand-flat, and was much lower in the mud-flat without vegetation (Fig. 5c).

Zostera roots penetrate approximately $5 \mathrm{~cm}$ while Scirpus and Spartina may have active roots down to $20 \mathrm{~cm}$ in depth. The potential nutrient efflux from plants' rhizospheres during the night shows that at this time of the year Scirpus salt marsh acts as a sink of nutrients, Spartina salt marsh may contribute to the efflux of nutrients during the night period, especially phosphate, and Zostera beds may have a comparatively strong contribution to phosphate efflux during the night (Fig. 6).

\section{Discussion}

The day-night amount of nutrients exchanged in the sediment pore-water without vegetation and the day-night sediment-water exchanges in plants' rhizospheres seem quite different. However, LOI can express the potential availability of nutrients in the sediment, explaining the low phosphorus and nitrogen concentration in the sand-flat profiles compared with the high concentration in the
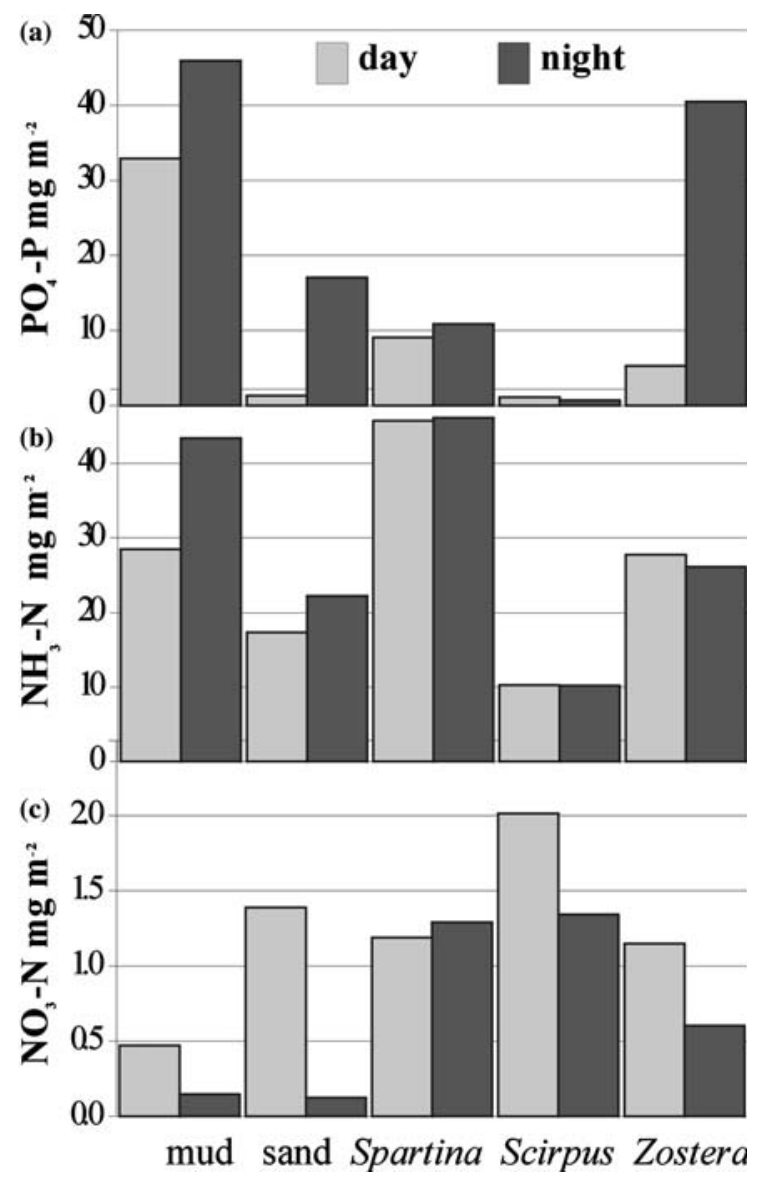

Figure 5. Total amount of nutrients in Spartina, Scirpus and Zostera rhizosphere, and in mud- and sand-flats without vegetation, during day and night: (a) Phosphate; (b) Ammonia; (c) Nitrate.

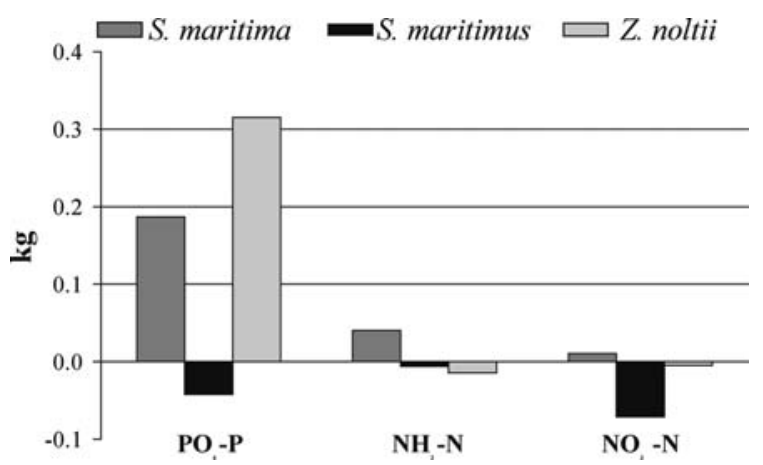

Figure 6. The potential night efflux of phosphate, ammonia and nitrate from Spartina, Scirpus and Zostera rhizospheres. 
mud-flat (Falcão \& Vale, 1998), as particle-water equilibrium and reactions between these two phases can influence the nutrient availability for plant uptake. On the other hand, in the plant rhizosphere, nutrients may diffuse towards the roots and the uptake of water by plants creates advective transport of water and salt in the direction of the roots. Additionally, the sediment phosphate adsorption capacity and the form of dissolved inorganic nitrogen will be dependent upon the oxic state of the sediment, (e.g., Flindt, 1994; Cowan et al., 1996). In the areas without vegetation, the significant differences between day and night profiles, with higher phosphate and ammonia concentrations during the night coupled with the extremely low nitrate concentration, may reflect oxygen depletion due to respiration, which during the day may be compensated by autotrophic oxygen production from associated microalgae. In addition, the integrated low amount of nitrate and the high ammonia pool most likely also reflect the oxygen limitation of the nitrification process (Kamp-Nielsen \& Flindt, 1993; Flindt, 1994; Flindt et al., 1999). In the colonised sediments day-night variation of nutrient concentrations in sediment pore-water seemed to be very much dependent on plant root biomass and penetration in depth. In spring, the average biomass of Zostera roots in the top $5 \mathrm{~cm}$ of sediment is $25 \pm 8 \mathrm{~g}$ Dwt $\mathrm{m}^{2}$, while salt marsh plants have active roots down to $20 \mathrm{~cm}$ in depth and the average roots biomass is respectively $2183 \pm 1119 \mathrm{~g}$ Dwt $\mathrm{m}^{2}$ for Spartina and $3374 \pm 890 \mathrm{~g}$ Dwt $\mathrm{m}^{2}$ for Scirpus. These results suggest that in spring these species may enhance the nutrient uptake for growth proposes and promote a more oxidized rhizosphere, which explains the lower phosphate and ammonia concentrations in the interstitial water during day and night situations, when compared with bare muddy sediments. Nutrient profiles in Zostera beds should be compared to sandy-muddy bare sediment.

Macrophytes can influence the nitrogen cycling directly by taking up dissolved inorganic nitrogen for growth purposes. Additionally, ammonification may be enhanced by re-mineralisation of particulate organic matter (Kemp et al., 1984), by dissolved organic nitrogen released form the plant roots (Smith et al., 1988) and from breakdown of senescent plant material (Kenworthy \& Thayer, 1984). The nitrification process is generally limited by low oxygen and ammonia concentrations (Henriksen \& Kemp, 1988).

The sediment pore-water profiles also showed that plant coverage influences differently the nutrient profiles. Results show that $Z$. noltii, $S$. maritima and $S$. maritimus have a specific interaction with the sediment, as has been suggested for other species (Wigand et al., 1997). Significant differences between various plant rhizosphere nutrient profiles may result from the depth of root penetration, plant biomass and plant physiology.

Zostera noltii is able to take-up nutrients from the water column through the leaves and from the interstitial water via the rhizomes (Short, 1987). However, it has been shown that rooted submersed macrophytes are able to take up almost all phosphorus needed from the interstitial water (Flindt et al., 1999). The penetration of Zostera roots into the sediment aerates the upper layers, and allows oxygen to penetrate into the top few centimetres (Short, 1987). The low phosphate concentrations during the day, especially in the top $5 \mathrm{~cm}$ of the sediment, may express the increased P-adsorption due to the release of oxygen, and the consumption for growth proposes. However, during the night, and considering the top $10 \mathrm{~cm}$ of the sediment, $Z$. noltii beds may make a comparatively strong contribution to the phosphate efflux, due to the prevalence of heterotrophic processes and the fact that the rooting zone only covers $50 \%$ of the sediment column. In Zostera beds, nitrogen is usually the limiting element and is most easily absorbed as ammonium (Short, 1987). Relatively high nitrification rates in Zostera beds have been attributed to the release of oxygen from roots (Barko et al., 1991; Flindt, 1994). Additionally, stimulated denitrification has been explained by enhanced nitrification and leakage of easily degradable dissolved organic carbon (Flindt, 1994).

Both salt marsh species have the ability to transport oxygen to the belowground parts, down to $20 \mathrm{~cm}$ depth into otherwise impermeable sediments, where it is used for root respiration and oxidation of the rhizosphere (Adams \& Bate, 1995; Cleavering et al., 1995). This process may lead to the precipitation of iron oxides around the roots (Vale et al., 1990), and ultimately increase the phosphate adsorption capacity of the sediment 
(Berner \& Berner, 1996). Moreover, rhizosphere oxidation can provide aerobic micro-sites with available nitrate, and mitigate the likely predominance of ammonium over much of the marshes (Adam, 1990; Kamp-Nielsen \& Flindt, 1993). The oxygen diffusion to the sediment is driven by photosynthetic oxygen production (Azzoni et al., 2001), and the fact that the Scirpus population is reaching maximum density and biomass, may enhance both biotic and abiotic reoxidation of reduced compounds. Additionally, the likely increase in oxidised surface area of Scirpus compared to Spartina suggests a higher nitrification rate in the root rhizosphere and subsequently denitrification. Further on, denitrification may be stimulated by high quality dissolved organic carbon released by the roots (Kamp-Nielsen \& Flindt, 1993; Flindt et al., 1999). On the other hand, Scirpus is a C3 photosynthetic mechanism type (Boschker et al., 1999), while Spartina is an alternative (C4) type (Carter, 1988), or just a C4 type (Benito \& Onaindia, 1991). It has been suggested that plants with a $\mathrm{C} 4$ photosynthetic pathway have, at least theoretically, a number of competitive advantages over C3 species (Adam, 1990), namely a higher potential productivity, higher water-use efficiency and also a more efficient use of available nitrogen (Adam, 1990). Furthermore, Spartina has continuous growth, and considering the top $10 \mathrm{~cm}$ were the rooting zone covers $100 \%$ of the sediment, this salt marsh area may contribute to the efflux of phosphate during the night period.

Our results show that nutrients are intensely exchanged inside the colonised sediments, and suggest that coupling between plant and sediment is a species-specific process, allowing a more comprehensive and environmentally correct understanding of estuarine systems functioning.

\section{Acknowledgements}

This study was carried out in the scope of the POCTI - Formar e Qualificar - Medida 1.1 programme (Portugal) through a Post-Doctoral grant (SFRH/BPD/5650/2001). Furthermore, it was supported by the research project DYNAMOD (POCTI/M6S137431/2001) funded by the Portuguese FCT. The authors are indebted to all colleagues from IMAR-Coimbra who assisted in the field and laboratory work. The authors would like to thank the Freshwater Biological Laboratory, University of Copenhagen, Denmark, for the support of this study.

\section{References}

Adam, P., 1990. Plants and Salinity in Salt Marsh Ecology. Cambridge University Press, Cambridge, pp. 208-277.

Adams, J. B. \& G. C. Bate, 1995. Ecological implications of tolerance of salinity and inundation by Spartina maritima. Aquatic Botany. 52: 183-191.

Alpkem, 1990. Rapid Flow Analyser - Methodology A303-S202, A303-S170, A303-S020. ALPKEM Corporation, Clackamas, Oregon, USA.

Andersen, F. Ø. \& P. Ring, 1999. Comparison of phosphorus release from littoral and profundal sediments in a shallow eutrophic lake. Hydrobiologia 408/409: 175-183.

Anderson, I. C., C. R. Tobias, B. B. Neikirk \& R. L. Wetzel, 1997. Development of a process-based nitrogen mass balance model for Virginia (USA) Spartina alterniflora salt marsh: implications for net DIN flux. Marine Ecology Progress Series 29: 13-27.

Azzoni, R. G., M. Giordani, D. T. Bartoli \& P. Welsh Viaroli, 2001. Iron, sulphur and phosphorus cycling in the rhizosphere sediments of an euthrophic Ruppia cirrhosa meadow (Valle Smarlacca, Italy). Journal of Sea Research 45: 15-26.

Barko, J. W., D. Gunnison \& S. R. Carpenter, 1991. Sediment interactions with submersed macrophyte growth and community dynamics. Aquatic Botany 41: 41-65.

Benito, I. \& M. Onaindia, 1991. Biomass and aboveground production of four angiosperms in Cantabrian (N. Spain) salt marshes. Vegetario 96: 165-175.

Berner, E. K. \& R. Berner, 1996. Marginal marine environments, estuaries. Global Environment, Water, Air and Geochemical Cycles. Chapter 7. Estuaries, Prentica-Hall Inc, New Jersey: 284-311.

Boschker, H. T. S., J. F. C. de Brouwer \& T. E. Cappenberg, 1999. The contribution of macrophyte-derived organic matter to microbial biomass in salt-marsh sediment: Stable isotope analysis of microbial biomarkers. Limnology and Oceanography 44: 309-319.

Caçador, I., C. Vale \& F. Catarino, 1996. Accumulation of Zn, $\mathrm{Pb}, \mathrm{Cr}$ and $\mathrm{Ni}$ in sediments between roots of the Tagus estuary salt marshes, Portugal. Estuarine, Coastal and Shelf Science 42: 393-403.

Caçador, I., C. Vale \& F. Catarino, 2000. Seasonal variation of $\mathrm{Zn}, \mathrm{Pb}, \mathrm{Cu}$ and $\mathrm{Cd}$ concentrations in the root-sediment system of Spatina maritima and Halimione portugaloides from Tagus estuary salt marshes. Marine Environment Research 49: 279-290.

Cardoso, P. G., A. I. Lillebø, M. A. Pardal, S. M. Ferreira \& J. C. Marques, 2002. The effect of different primary producers on Hydrobia ulvae population dynamics: a case study in a temperate intertidal estuary. Journal Experimental Marine Biology Ecology 277: 173-195. 
Cartaxana, P. \& D. Lloyd, 1999. $\mathrm{N}_{2}, \mathrm{~N}_{2} \mathrm{O}$ and $\mathrm{O}_{2}$ profiles in a Tagus estuary salt marsh. Estuarine, Coastal Shelf Science 48: 751-756.

Carter, R. W. G., 1988. Coastal wetlands, salt marshes. Coastal Environments. An Introduction to the Physical, Ecological and Cultural Systems of Coastlines. Ac. Press, London: 335-346.

Cowan, J. L. W., J. R. Pennock \& W. R. Boynton, 1996. Seasonal and interannual patterns of sediment nutrient and oxygen fluxes in Mobile Bay, Alabama (USA): regulating factors and ecological significance. Marine Ecology Progress Series 141: 229-245.

Falcão, M \& C. Vale, 1998. Sediment-water exchanges of ammonium and phosphate in intertidal and subtidal areas of a mesotidal coastal lagoon (Ria Formosa). Hydrobiologia 373/374: 193-201.

Flindt, M. R., 1994. Measurements of nutrient fluxes and mass balances by on-line in situ dialysis in a Zostera marina bed culture. Verhandlungen Internationale Vereinigung für theoretische und angewandte Limnologie 25: 2259-2264.

Flindt, M. R., M. A. Pardal, A. I. Lillebø, I. Martins \& J. C. Marques, 1999. Nutrient cycling and plant dynamic in estuaries: a brief review. Acta Oecologica 20: 237-248.

Henriksen, K. \& W. M. Kemp, 1988. Nitrification in estuarine and coastal marine sediments: methods, patterns and regulating factors. In Blackburn, T. H. \& J. Sorensen (eds.) Nitrogen Cycling in Coastal Marine Environments. John Wiley and sons, New York: 207-250.

Kamp-Nielsen, L. \& M. R. Flindt, 1993. On-line recording of porewater profiles from in situ dialysis. Verhandlungen Internationale Vereinigung für theoretische und angewandte Limnologie 25: 151-156.

Karagatzides, J. D. \& I. Hutchinson, 1991. Intraspecific comparison of biomass dynamics in Scirpus americanus and Scirpus maritimus on the Fraser river delta. Journal of Ecology 79: 459-476.

Kemp, W. M., W. R. Boynton, R. R. Twilley, J. C. Stevenson \& L. G. Ward, 1984. Influeces of submersed vascular plants on ecological processes in upper Chesapeake Bay. In Kennedy, V. S. (ed.) The Estuary as a Filter. Academic Press, New York: 367-394.

Kenworthy, W. J. \& G. W. Thayer, 1984. Production and decomposition of the roots and rhizomes of seagrasses,
Zostera marina and Thalassia testudinum, in temperate and subtropical marine ecosystems. Bulletin of Marine Science 35: $364-379$.

Lieffers, V. J. \& J. M. Shay, 1982. Seasonal growth and standing crop of Scirpus maritimus var. paludosus in Saskatchewan. Canadian Journal of Botany 60: 117-125.

Lillebø, A. I., M. A. Pardal, J. M. Neto \& J. C. Marques, 2003. Salinity as the major factor affecting Scirpus maritimus annual dynamics. Evidence from field data and greenhouse experiment. Aquatic Botany 77: 111-120.

Marques, J. C., M. A. Pardal, S. N. Nielsen \& S. E. Jørgensen, 1997. Analysis of the properties of exergy and biodiversity along an estuarine gradient of eutrophication. Ecological Modelling 62: 155-167.

Marques, J. C., S. N. Nielsen, M. A. Pardal \& S. E. Jørgensen, 2003. Impact of eutrophication and river management within a framework of ecosystem theories. Ecological Modelling 166: $147-168$.

Sánchez, J. M., X. L. Otero, J. Izco \& F. Marcías, 1997. Growth form and population density of Spartina maritima (Curtis) Fernald in Northwest Spain. Wetlands 17: 368-374.

Sánchez, J. M., X. L. Otero \& J. Izco, 1998. Relation between vegetation and environmental characteristics in a salt-marsh system on the coast of Northwest Spain. Plant Ecology 136: $1-8$.

Short, F. T., 1987. The effects of sediment nutrients on eelgrasses; literature review and mesocosm experiment. Aquatic Botany 27: 41-57.

Smith, R. D., A. M. Pregnall \& R. S. Alberte, 1988. Effects of anaerobiosis on root metabolism of Zostera marina (eelgrass): Implications for survival in reducing sediments. Marine Biology 98: 131-141.

Vale, C., F. M. Catarino, C. Cortesão \& M. I. Caçador, 1990. Presence of metal-rich rhizoconcretions on the roots of Spartina maritima from the salt marshes of the Tagus estuary, Portugal. Science Total Environment 97/98: 617-626.

Wigand, C., J. C. Stevenson \& J. C. Cornwell, 1997. Effects of different submersed macrophytes on sediment biogeochemistry. Aquatic Botany 56: 233-244.

Zar, J., 1996. Biostatistical Analysis, 3rd edn. Prentice-hall International Inc., Simon and Schuster/A viacom Company, Upper Saddle River, NJ, USA, 662 pp. 